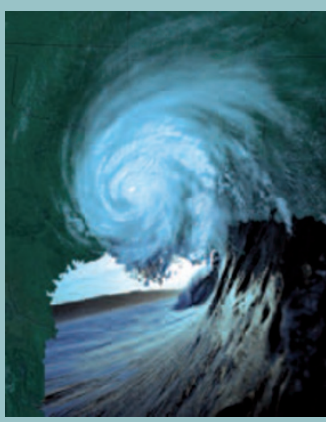

Cover Design by Karl Smart

Nature Reports Climate Change

EDITORIAL OFFICE

News Editor: Olive Heffernan

Production Editor: Jacqueline Limb

Sub Editor: Rosalind Portman

Art Editor: Karl Smart

Web Designer: Miles Davies

\section{MANAGEMENT OFFICE}

Publishing Director: David Swinbanks

Publisher: Jason Wilde

Managing Production Editor: Donald McDonald

Web Design Manager: Glennis McGregor

Marketing: Katy Dunningham

Editor in Chief, Nature Publications:

Philip Campbell

Advertising Manager, Physical Sciences:

Simon Allardice

Sponsorship: Emma Green

Nature - www.nature.com/nature

The Macmillan Building, 4 Crinan St

London N1 9XW, UK

Tel: +44 (0) 2078334000

e-mail: nature@nature.com

VISIT NATURE REPORTS

CLIMATE CHANGE ONLINE

World Wide Web

http://www.nature.com/reports/climatechange

SUBSCRIPTIONS AND CUSTOMER SERVICES

For UK/Europe (excluding Japan):

Nature Publishing Group, Subscriptions, Brunel

Road, Basingstoke, Hants, RG21 6XS, UK.

Tel: +44 (0) 1256329242.

Subscriptions and customer services for

Americas - including Canada, Latin America

and the Caribbean: Nature Publishing Group,

Subscription Department, PO Box 5161,

Brentwood, TN 37024-5161.

Tel: (800) 5242688 (US) or 6158505315

(outside the US).

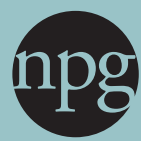

nature publishing group

nature

REPORTS climate change

\section{AN END TO HOT AIR}

Climate change is the most far reaching of the great challenges of the twenty-first century. It affects not only all people on the planet, it will also govern the future of the rest of the biosphere. Because so much, and so many, are at stake, the question of how to minimize and deal with climate change remains hugely controversial.

Making good choices on how we deal with such change requires accurate information and open discussion. It is now firmly established that human activity is largely responsible for the climatic future, but there is still much to say, and to learn, about the extent and the timing of the changes to come. Yet, despite a 20 -fold increase in coverage of climate change in the UK since the 1980s (and a fivefold increase in the US over the same period), the facts of climate change remain a low priority for the mainstream media. Readers are often left out in the cold when it comes to separating issues of consensus from debate, fact from opinion and even fact from fiction.

In light of the need for greater discussion and understanding and easier access to information, Nature has launched a new online resource to extend its reporting of the issue. Nature Reports: Climate Change is freely accessible and is updated weekly with unique news, comment, analysis, reviews, features and more. Every month, the content is collated into a downloadable digital edition, of which this is the first issue. Each issue can be cited and archived just like a magazine - but without the carbon footprint that goes with ink on paper. If you prefer, you can get some of the material in audio form through our monthly podcasts coming shortly.

Aside from providing authoritative coverage of climate science and its wider implications, Nature Reports: Climate Change is an interactive hub, with opportunities for readers to contribute by commenting on our Climate Feedback blog and by voting on recent papers in our Journal Club.

The website complements Nature's existing coverage of climate change, both in print and online. Together with sister sites on Avian Flu and Stem Cells, Nature Reports represent a new venture for Nature, providing site-specific online coverage of highly topical and controversial issues of interest to the world at large. We hope you enjoy reading and joining our discussions.

OLIVE HEFFERNAN, NEWS EDITOR

\section{RESEARCH HIGHLIGHTS}

2 Mitigation:

Barking up the wrong tree

Samia Mantoura

Biodiversity \& Ecology:

Fruiting fungi

Eric Smalley

Ocean Science:

Twilight zone transport

Eric Smalley

Extreme Events:

Rainfall rules

Harvey Leifert

3 Biodiversity \& Ecology: Healthiest corals hit hardest Harvey Leifert

Atmospheric Science:

Winds of change

Samia Mantoura

\section{NEWS FEATURE}

4 Carbon storage deep down under

Hannah Hoag

\section{COMMENTARY}

6 Averting disaster: at what cost Jeffrey D. Sachs

\section{BOOKS \& ARTS}

\section{Optional offsetting}

Matthew Lockwood

\section{NEWS \& VIEWS}

10 Ocean Sciences: Iron findings Phillip W. Boyd

\section{FOCUS FEATURE}

12 Post-Kyoto pact: shaping the successor Amanda Leigh Haag

\section{POLICY WATCH}

\section{Washington Watch}

Kevin Vranes 